\title{
Malaysian Y Generation Consumer Research: Does Gender and Technology Literacy affirmative towards E-commerce activities?
}

\author{
*Dileep Kumar M., Normala S, Govindarajo, Harvi, S. \\ Othman Yeop Abdullah Graduate School of Business, Universiti Utara Malaysia \\ *prof.mdk@gmail.com
}

\begin{abstract}
The last two decades have experienced rapid expansion of information and communication technology. This wide application of internet stated its influence on attitude and adoption of internet among various generations. The generation Y which is "the millennial generation", are the major one who has connected with the technology, especially with internet usage, and is widely in every aspect of life. They adopt technology application in shopping product and services, moving away from traditional purchasing behavior of consumer. Though various studies have come out in the area of generation Y and technology adoption, very less studies are observed connecting gender, and contextualizing the topic to the Malaysian context, considering the consumer internet usage attitude and e-commerce activities. Hence this particular study, then observed and analyzed generation Y attitude towards internet usage and e-commerce activities with its moderating effect of gender variation.
\end{abstract}

Keywords: Y Generation, Consumer, Technology Literacy, E-commerce

\section{Introduction}

In the last two decades, there is an increasing trend of the internet usage among organizations and individuals who have contributed a major impact to our perspective to the world as a global village, by reducing the spatial separation between regions and enabling information exchange worldwide more freely and rapidly. Most of the world inhabitants now live and work in what we called as network society (Castells, 2000). This globalization has had a great impact to almost every sector of modern society including the business, education, healthcare, entertainment and social interactions. Today the internet universally regarded as one of the important aspect to the growth of business and become an indispensable resource. In terms of demographics aspect of internet users revealed that the largest proportion of internet users in the United Kingdom (data collected by Office for National Statistic United Kingdom in 2011) who belonged to 16-24 years old occupy 98.8 percent. This number represents 7.19 million people, and only 64.000 people in this youngest category had never used the internet. Another survey conducted by (Pew Research Center, 2012)Internet\& American Life Project in 2012 revealed that the largest proportion of internet users in the United States was in the age group of 18 - 29, at 94\% with the margin of error is approximately 2.3 percent. The pattern of largest internet user is quite similar the several developed countries and some of the developing countries. Thus, we can understand that the largest proportion of internet user is in generation Y. How far this generation $\mathrm{Y}$ attitude related to their ecommerce activities is less researched into. This particular study tries to relate socio demographic variable gender with the internet attitude and ecommerce activities in this research.

\section{Review of literature}

Generation $\mathrm{Y}$ has been recognized as a new market segment that will bring change in the platform of internet in an enormously connected world. This generation generally has grown up in the strong economic condition, thus this generation has a high purchasing power (Blakewell \& Mitchell, 2003). This generation is a unique target for e-commerce marketers as well as a unique target to study their behavior towards e-commerce (Djamasbi, Siegel, \& Tullis, 2010). Generation Y are spending aggressively on the internet and luxury goods are their most frequently purchased item in the internet (American Express, 2012). The study conducted by American Express indicates that almost 31 percent of e-commerce consumers were belong to generation Y, while generation X accounted for 19 percent and lastly baby boomers were 19 percent. The generation Y members has been categorized as astute at finding products on the internet, moreover generation Y can fully utilize internet for e-commerce such as searching product item, selecting channel, and find information about the product (Brafton Editorial, 2012). Papastergiou (2005) stated that even in this internet base era, not everybody may have equal ability and 
chance to access and use the technology itself. This matter arise as a parts of digital divide problem, many aspects contribute to this disparity such as gender. The gender gap in internet adoption of internet may exist because male and female have a different perspective on technology; therefore, it will influence their computer and internet access usage (Ono, 2003; Bimber, 2000). In general, men tend to have more hours spending on the internet than women; men have more intense access than women. Currently two third of the planet still have no access to the internet, in addition the unconnected people mostly are woman. Surprisingly there are some countries force women to keep offline (The Broadband Comission Working Group on Broadband \& Gender, 2013).

In the massive dependency and expansion of internet, it was found that is not everyone has equal opportunities to access and usage it. (Papastergiou \& Solomonidou, 2005). This matter arise as a parts of digital divide problem, many factor contribute to this disparity such as income, educational level, class, race, gender, and geographical location. As cited in $(\mathrm{Ono}, 2003)$ the gender gap in the adoption of internet may exist because male and female are different in the socio economic status on average, thus it will influences computer and internet access use (Bimber, 2000). Latest research in September 2013 conducted by United National Development Program which focusing broadband and gender indicates that generally, men tend to have more hours spending time in the internet than women. The research reported that men have more intense access than women. It is almost twenty years after the birth of Internet, two third of the planet still have no access to the internet, in addition the unconnected people mostly are women. Surprisingly some countries force women to keep offline through their legal system and politics. The gender inequalities still happening in the information ages like nowadays, and it can be potential harmful to leave women behind in term of information technology. (The Broadband Comission Working Group on Broadband \& Gender, 2013).

The gender gap in technology and their attitude towards Internet have been reported by several researchers. For instance early study in the 1996 reported that women experienced greater disorientation level and disenchantment in relation to the internet compared to males (Ford \& Miller, 1996). According to (Morahan-Martin \& Janet, 1998) informed that women respondent went online less intense, spent less time to surf digitally and utilized internet for narrower purposes than males.It has been pointed out by previous researcher or scholars, that there is a gender disparity in the online use and access of computer. The study like women, girls and computer by Marlaine Lockeheed in 1985, Computer and girls: rethinking the issue sex roles by Jan Hawkins 1985 and Gendered technology and gendered practice by Rakow in 1988. Most of the studies identified that that internet usage and access mostly dominated by men. An earlier study done by Nachmias et al. (2001), found that males are spending more time in the internet compared to females that they prefer using internet for resource downloading, website creation and discussion group. Study done by Nachmias, suggested that gender differences in technology does exist with higher score attitude towards internet for males respondent and more extensive usage of internet compared to females.Study conducted in the Taiwanese high school student also reveal that males showed more positive attitude towards internet than female student and student withmore internet experience tend to have better attitude towards internet. The term digital divide still exist in Taiwanese high school student (Tsai \& Lin, 2007).

Another study supported the issue about gender and attitudes towards internet had been pointed out by Madell and Muncer in (2004), from their research discovered that males prefer to use internet, and mostly they are having own their own email addresses, web site, and they have spent longer hours contrast to the opposite gender. In line with Madell and Muncer (2004), a study conducted in Malaysia reported that male respondent spent more hours in the internet (Luan, Fung, \& Atan, 2008). Another study done in China and United Kingdom also reported that in general respondent agreed that internet is useful to gain information, however men respondents indicated positive attitude towards internet (Li \& Kirkup, 2007). Furthermore males are more utilizing technology such as internet for correspondence, more intense and have more positive attitude than females (Muncer, 2004; Sherman et al., 2000). In contrast according to $(\mathrm{Ono}, 2003)$ the trend of gender gap in the internet field started to diminishing step by step. In the mid 1990s women were significantly using internet lesser than man but the gender gap in the internet diminished in the 2000s, the difference tend to diminish but not necessarily disappear altogether. A latest research conducted in the early 2013 at Panjab University, India research reveals that there is no difference between male and female attitude towards internet. This phenomenon happened due to the respondent have, high level of computer literacy, high rate access to internet and able to operate the latest tools (Suri \& Sharma, 2013). This result in line with (Paris, 2004) showed that there is no significant difference between male and female in attitude towards internet. 
Previous studies from several researchers has reported that in general gender gap does exist and affecting their attitude towards internet, therefore gender might be moderate the attitude towards internet and e-commerce. Several scholars alleged that male and female differ in their processing information (Holbrook, 1986). Principally men and women receive stimuli in consumption such as graphic or text. While women more respond on imagery or graphic stimuli, men more intend to description of the products. This observable fact may lead to the moderating role for attitude towards internet and e-commerce, because promoting product through e-commerce bring different stimuli compared to the brick and mortar or conventional shop which is more emphasizing on verbal stimuli.According to (Korgaonkar \& Wolin, 1999) demographic variable such as age, income, and education were the variable that significantly with the attitude towards internet and significantly correlated to the e-commerce activities. As cited by Joines et al. (2003) age, income, and education still be important predictors of e-commerce activities. In line with Joines et al. (2003) study conducted by Atlas (2000) reported that gender and education are notably related to their activities in the e-commerce field.

The influence of gender upon decision making on the e-commerce has been a subject of special interest in the field of online marketing, it has also been analyzed with regard the process of acceptance of new information technologies, concluding the information technology characteristics and use are evaluated differently, depending on the gender of individual (Venkatesh \& Morris, 2000). According to (Sun \& Zhang, 2006) state three traits determine these differences:

- Men are more pragmatic;

- Women are having more anxiousness when faced with new activities; and

- Women are more strongly influence by immediate environment.

The greater the attitude towards internet, the greater the number of exchanges completed, and the more positive is the attitude towards online shopping (Hernandez, Jimenez, \& Martı'n, 2009). While trying to assess moderating effect of age, gender and income to e-commerce, it was reported that gender moderating user attitude toward internet and their attitude towards e-commerce (Hernandez, Jimenez, \& Martı́n, 2009)

Problem Formulation: According to Malaysian Communication and Media Commission (MCMC) in 2010 reported that only 9.3 percent of internet user in Malaysia who actually utilize internet as business media to conduct transaction, therefore it portray that only small portion of Malaysian that interest to utilize this technology and showed negative attitude towards e-commerce. Even though a lot of studies previously have emphasized on understanding prominent factors that may lead to intention to use ecommerce but there are no positive result as to what factors contributing to customer intention towards e-commerce. Moreover there is lack of study or research conducted in the Malaysian e-commerce practices correlating the gender differences in the internet usages and involvement in the e commerce activities. Hence, it is necessary to understand the attitude of generation y consumers on e-commerce. The study identifies its research topic as "Does gender and Technology Literacy affirmative towards e-commerce activities?"

Research framework: Conceptual framework is needed in this study to show possible course of action or presenting preferred approach to an idea thought. In this study deals with the views of technology, general online activities, attitude towards internet, and user computer literacy, ultimately all of this factor will lead to their attitude towards e-commerce. The framework of this idea is illustrated as figure below.

Figure 1: Research Framework

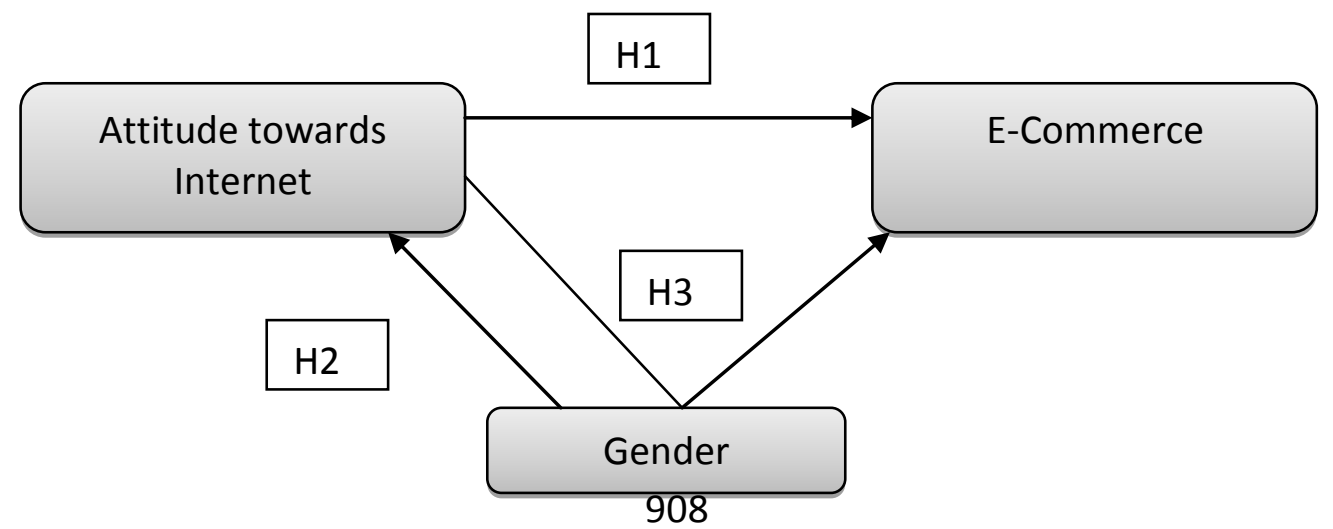




\section{Hypothesis}

- Generation Y will have affirmative attitude toward internet on their e-commerce activities.

- There will be significant relationship between gender and attitude towards internet among generation $\mathrm{Y}$

- Gender moderate the relationship between attitude toward internet and e-commerce among generation $Y$

Generation: Generation, in the daily culture there are two kinds of different meaning of generation, which is referring to kinship and other referring to membership of age group. Meanwhile, in the sociological literature divide generation into two perspectives which is the socio cultural based and cohort historical based. Ultimately, the key term of generation is used in daily term to differentiate and grouping based on age.

Attitude: Attitude is a learned predisposition to behave in a consistently favorable and unfavorable way with respect to a given object. The object in this definition can refer to any person, product, service, brand or marketing concept such as advertising. Attitudes are learned and can be the result of past experience and or information acquired from other people or the mass media (Schiffman, Kanuk, \& Hansen, 2008).

E-commerce: E-commerce (electronic commerce or EC) is the buying and selling of goods and services on the Internet, especially the World Wide Web. In practice, this term and a newer term, e-business, are often used interchangeably. For online retail selling, the term e-tailing is sometimes used.

\section{Methodology}

Unit of Analysis: According to Sekaran (2003), unit of analysis refers to the level of aggregation of the data collected during the subsequent data analysis stage. This research, considered working professionals in Kuala Lumpur and Selangor are the unit of analysis; hence the unit of analysis in this study is individual. All of them are staffs who are living or work in service companies around Kuala Lumpur and Selangor state.

Research Design: Right after identifying the variable in the problem statement and developing the theoretical framework, the following step is designing the research in such a way that the essential data can be gathered and analyzed to arrive at solution (Sekaran, 2003). There are various type of research design, for instance like exploratory study, descriptive study, experimental study. This research is applying descriptive study design in order to ascertain and able to describe the characteristic of the variables in the particular situation. This particular research attempt to investigate the generation $\mathrm{Y}$ attitudes towards usage of internet for e-commerce, with one independent variable the attitude toward internet with moderating variable, gender. The entire variable were not manipulated or controlled, thus no artificial setting was created. The questionnaire-based survey was used to collect detailed information that reveals the characteristic of generation Y towards the usage of internet for e-commerce.

Research Population: The population of research refers to the entire group of people, event, or things of interest that researcher willing to investigate (Sekaran, 2003). In this particular research, the sample for this research focused on working professional who live around Kuala Lumpur Federal Territory and Selangor State, more precisely the author has selected MSC (Multimedia Super Corridor) landmark such as Cyberjaya, Selangor, TPM (Technology Park Malaysia) and Kuala Lumpur City Centre, since there are lots of office spaces and many local and multinational (MNC) companies were established in Multimedia Super Corridor (MSC) landmark. Multimedia Super Corridor landmark are special territory in Malaysia established in order to accelerate Malaysian economic and transform Malaysia as stated in the vision 2020 as a modern country, with fully adoption of knowledge based. In addition the companies employ definitely knowledge workers round the clock. Further the companies mostly employ worker who is considered as a member of generation Y, their age are around 18 to 33 (in the year 2014). According to Lohse, Belman, and Johnson (2000) and Keating (2000) found that the internet users are more likely younger, well educated, and prosperous. Hence Cyberjaya, Technology Park Malaysia (TPM) and Kuala Lumpur City Centre are suitable place to conduct this research

Sample Size: Sekaran (2003) define a sample as a small subset of population. A sufficient sample is importantly needed to generalize to the population (Hair, Money, Samouel, \& Page, 2007). Roscoe (1975) proposed that a sample size larger than 30 and less than 500 are required for appropriate research. 
Barlett, Kotrlik and Higgins (2001) in their research Organizational Survey: Determining Appropriate Sample Size in Survey Research proposed that 200 - 300 sample size is sufficient. In total, ten (confidential) companies in three different areas have selected in order to gain respondent for this particular research and 450 questionnaires has been distributed. The following table shows the distributed questionnaires in the three different areas.

Table 1: Questionnaires Distribution

\begin{tabular}{lllll}
\hline Company & $\begin{array}{l}\text { Junior } \\
\text { Management }\end{array}$ & $\begin{array}{l}\text { Middle } \\
\text { Management }\end{array}$ & $\begin{array}{l}\text { Senior } \\
\text { Management }\end{array}$ & Total \\
\hline A & 20 & 15 & 5 & 40 \\
B & 25 & 15 & 4 & 44 \\
B & 35 & 20 & 7 & 62 \\
D & 30 & 20 & 5 & 55 \\
E & 25 & 15 & 3 & 43 \\
F & 20 & 15 & 5 & 40 \\
G & 25 & 15 & 4 & 44 \\
H & 30 & 20 & 5 & 55 \\
I & 20 & 10 & 4 & 34 \\
J & 20 & 10 & 3 & 33 \\
TOTAL & & & & 450 \\
\hline
\end{tabular}

Sampling Design: Sekaran (2003) define sampling as the process of selecting the right individuals, objects, or events as representatives for the entire population. There are two major types of sampling design: probability and non probability sampling. In the probability sampling, the elements in the population have some known, non-zero chance or probability of being selected as a sample subjects. While in non probability, the elements do not have known or predetermined chance of being selected as subject. The probability sampling design is used when the representativeness of the sample is prominent and wider generalizability (Sekaran, 2003).

The Sampling Method: Determining sampling method is prominent to select the sample in this study. The sampling method can be done in to two different categories: probability and non probability sampling methods. The probability sampling can be either unrestricted (simple random sampling) or restricted (complex probability sampling) (Sekaran, 2003).This survey applies stratified random sampling method. Stratified random sampling involves a process of stratification or segregation, followed by random selection of subject from each stratum (Sekaran, 2003). Proportionate random sampling is used because the sub population within population is vary, the respondent may come from junior level, middle level or even senior management level hence it is beneficial to take samples from each strata. Afterward simple random sampling is applied within each stratum

Measurements: This section explains the measurement for generation $Y$ attitude towards the usage of internet for e-commerce. The instruments were obtained and adapted from the previous literature.The first section identified the demographic aspects of the respondent, consist range of age, gender, education, income, frequency using internet, and wireless utilization among the selected respondent.The second section categorized respondents in two categories based on generational difference. A seven-point scale was used to measure. The measuring items were taken from the previous research that was done by Society for Human Resource Management (SHRM) in 2004The third section identified the Internet lifestyle. The measuring items were taken from previous research conducted by Swinyard and Smith(2003).The fourth section will find out attitude towards internet, the respondent were also asked the level of agreement or disagreement of each of the following item based on Mick and Fournier (1998) Paradoxes of InternetThe fifth section will assess knowledge of internet and computer technology among the respondent. The measuring items adopted from Computer Literacy Index (Swinyard \& Smith, 2003). 
Table 2: Summary of Questionnaire

\begin{tabular}{|c|c|c|}
\hline Variables & Number of Items & Items \\
\hline Section & Demographics: & \\
\hline Age & $x_{1}=0$ & Item 1 \\
\hline Gender & 1 & Item 2 \\
\hline Income & 1 & Item 3 \\
\hline Education & 1 & Item 4 \\
\hline Frequency using internet & 1 & Item 5 \\
\hline Wireless utilization & 1 & Item 6 \\
\hline Section 2 & & \\
\hline Generational Differences & 18 & Item $7-24$ \\
\hline Section 3 & & \\
\hline Internet Lifestyle (E-Commerce) & 36 & Item $25-61$ \\
\hline Section 4 & & \\
\hline Attitude Towards Internet & 8 & Item $62-69$ \\
\hline Section 5 & & \\
\hline Computer Literacy & 12 & Item $70-81$ \\
\hline
\end{tabular}

The measurement is considered as prominent aspect in every single research, in order to achieve meaningful data the measurement is needed. A scale is used to distinguish individual from one another based on the variables of interest in the particular study. According to Sekaran (2003) there are four types of scales: nominal, ordinal, interval, and ratio. In this research the interval scales are chosen. By using interval scale will allow the researcher to qualitatively distinguish respondent based on respondent agreeableness.

Table 3: Reliability Analysis

\begin{tabular}{ll}
\hline Variable & Croanbach's Alpha \\
\hline Generational Difference & 0.897 \\
Internet Lifestyle (E-Commerce) & 0.894 \\
Attitude Towards Internet & 0.813 \\
Computer Literacy & 0.848 \\
\hline
\end{tabular}

The table above displays the summary of reliability on the pilot test. Regarding to the initial test or pilot test, it shows that the Croanbach's Alpha for the generational difference is 0.897, while the Croanbach's Alpha for internet lifestyle (e-commerce) is 0.894, the Croanbach's Alpha results for attitude towards internet is 0.813 , and ultimately the Croanbach's Alpha for computer literacy is 0.848. Overall the results show that the Croanbach's Alpha exceeding 0.8. Hence, it can be assumed that the internal consistency for this questionnaire is considered to be good. Afterward, the questionnaire can be circulated to the real sample.

\section{Result}

This research is using multiple regressions analysis in order to test the research hypothesis. The objective of hypothesis testing is to measure how far the connection between dependent variable and independent variables. The significant value is a benchmark to measure significance level or connection between dependent variable and independent variables. If the significant value is less than 0.05 can be concluded that there is a significant correlation between independent and dependent variable, thus the null hypothesis or no directional relationship (correlation) is rejected.

Hypothesis 1: Generation $\mathrm{Y}$ will have affirmative attitude towards internet on their e-commerce activities. 
Table 4: Model summary Generation Y Attitude towards Internet on their E-commerce Model Summaryb

Model $\quad$ R R SquareAdjusted R SquareStd. Error of the Estimate

$1 \quad .879$ a $.687 \quad .683 \quad .58475$

a. Predictors: (Constant), AI

b. Dependent Variable: Ecomm

Based on model summary table no. 4 above, indicated that $\mathrm{R}$ square value is $0.687\left(\mathrm{R}^{2}=0.687\right)$. It means that 68.7 percent of e-commerce activities are predicted by attitude towards internet, in the meantime, the rest 31.3 percent were predicted by other factors which are not conducted in this research.

Table 5: ANOVA Generation Y Attitude towards Internet on their E-commerce

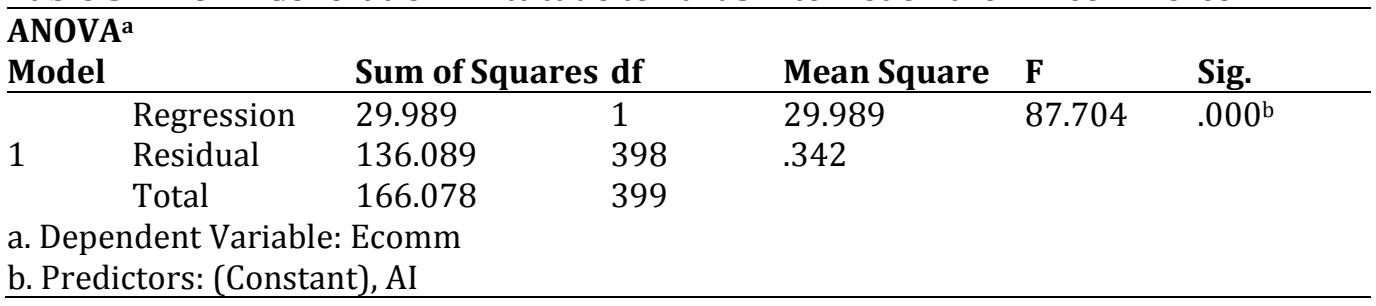

The ANOVA table no. 5 above shows that $F$ value is 87.704 and the significant level value is 0.000 . Followed by the df (degree of freedom), which represents the number of independent variable is 1 , which is e-commerce and 398 completed responses for the variable. The result shows that there is a significant relationship between attitude towards internet and e-commerce with prediction equation $(\mathrm{F}=87.704, \mathrm{p}<$ 0.05).

Table 6: Coefficient of Attitude towards Internet on E-commerce

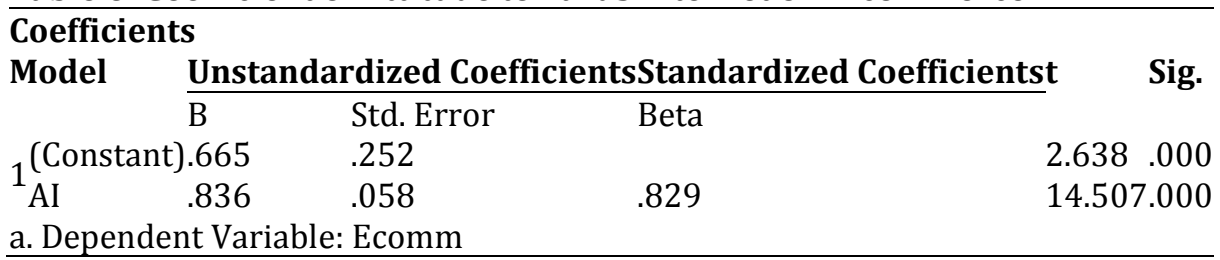

The coefficient table no. 6 above displays the coefficient level stated in Beta is 0.829 for attitude towards internet variable, which is strong, positive, and significant correlation $(\beta=0.829, \mathrm{p}<0.05)$ between attitude towards internet and e-commerce. Hence the result is positive significance between attitude towards internet and e-commerce activities. In conclusion, it has proven that hypothesis 1 (H1), based on the result $\mathrm{H} 1$ was accepted. There is a significant relationship between attitude towards internet and ecommerce.

Hypothesis 2: There will be significant relationship between gender and attitude towards internet among generation $\mathrm{Y}$.

Table 7: Model Summary Gender and Attitude towards Internet Model Summaryb

Model R R SquareAdjusted R SquareStd. Error of the Estimate

$1 \quad .577^{a} .333 \quad .272 \quad .71279$

a. Predictors: (Constant), Gender

b. Dependent Variable: AI

Table summary on gender and attitude towards internet above shows the R square values is $0.333\left(R^{2}=\right.$ 0.333). It means that gender contribute approximately 33 percent of attitude towards internet. In addition the $\mathrm{R}$ value is $\mathbf{0 . 5 7 7}$, and it is indicating positive value, therefore the relationship between two variables is positive relationship. 
Table 8: ANOVA Gender and Attitude towards Internet

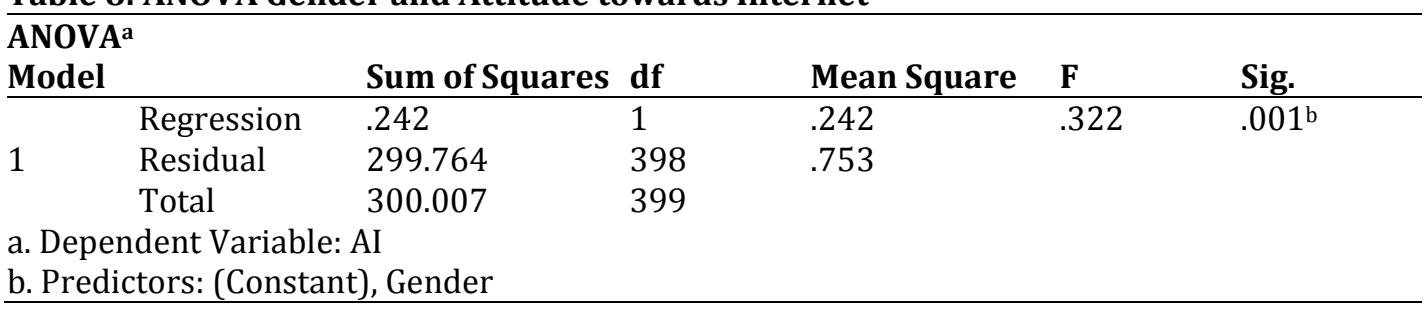

The ANOVA table no. 8 shows that F Value is 0.322 with the significant level 0.001 . Followed by df (degree of freedom) which represent the number of independent variable is 1 which is computer literacy and 398 total completed responses for the variable. The result shows that there is a significant relationship between gender and attitude towards internet with prediction equation $(\mathrm{F}=0.322, \mathrm{p}<0.05)$.

Table 9: Coefficient of Gender and Attitude towards Internet

\begin{tabular}{|c|c|c|c|c|}
\hline \multicolumn{5}{|c|}{ Coefficients $^{\mathbf{a}}$} \\
\hline \multirow[t]{2}{*}{ Model } & \multicolumn{3}{|c|}{ Unstandardized CoefficientsStandardized Coefficientst } & Sig. \\
\hline & $\overline{\mathrm{B}}$ & Std. Error & Beta & \\
\hline (Constant & 5.114 & .136 & & 37.695 .000 \\
\hline 1 Gender & .495 & .107 & .412 & 3.160 .001 \\
\hline
\end{tabular}

The coefficient table no. 9 above display the coefficient level stated in beta is 0.412 for gender variable, which is positive, and significant correlation $(\beta=0.412, p<0.05)$ between gender and attitude towards internet. Hence the result is positive, significant relationship between gender and attitude towards internet. In conclusion, it has proven that hypothesis 4 (H4), based on the result $\mathrm{H} 4$ was accepted, there is a significant relationship between gender and attitude towards internet.

Hypothesis 3: Gender moderates the relationship between attitude toward internet and e-commerce among generation $\mathrm{Y}$.

Table 10: Model Summary Gender Moderate Attitude towards Internet and E-commerce Model Summaryc

Model R R Square Adjusted R Square Std. Error of the Estimate

\begin{tabular}{|c|c|c|c|}
\hline 1 & $.311^{\mathrm{a}} .097$ & .095 & .61384 \\
\hline 2 & $.520^{\mathrm{b}} \quad .270$ & .267 & .55251 \\
\hline
\end{tabular}

Based on model summary above, it shows that model $1 \mathrm{R}$ square value is $0.097\left(\mathrm{R}^{2}=0.097\right)$ which means 9.7 percent e-commerce can be predicted by their gender. At the same time, in the model 2 the $\mathrm{R}$ square value is $0.270\left(\mathrm{R}^{2}=0.270\right)$ which means 27 percent of ecommerce can be predicted by their attitude towards internet with gender as moderator. In addition when analyze R value in the model 1 scores 0.311 and 0.520 as in the model 2 , it means the relationship between variables are positive

Table11: Coefficient of Gender Moderate Attitude towards Internet and E-commerce Coefficients

\begin{tabular}{|c|c|c|c|c|}
\hline \multirow[t]{2}{*}{ Model } & \multicolumn{4}{|c|}{$\underline{\text { Unstandardized CoefficientsStandardized Coefficientst }}$} \\
\hline & $\mathrm{B}$ & Std. Error & Beta & \\
\hline (Constant) & 5.294 & .096 & & 55.171 .000 \\
\hline Tender & .402 & .061 & .311 & 6.539 .000 \\
\hline (Constant) & 3.710 & .185 & & 20.091 .000 \\
\hline 2Gender & .386 & .055 & .300 & 6.986 .000 \\
\hline AI & .310 & .032 & .416 & 9.709 .000 \\
\hline
\end{tabular}


The coefficient table no. 11 above shows the coefficient level stated in Beta. The result indicates that gender has significant influence toward e-commerce, considering the significant level at 0.000 . In the fifth hypothesis, gender plays a role as moderator attitude towards internet and e-commerce. The result shows a significant relation because gender and e-commerce $(\beta=0.311, p<0.05)$ and gender moderate attitude towards internet and e-commerce $(\beta=0.300, \mathrm{p}<0.05)$. Hence it supported that in the fifth hypothesis (H3), that gender moderate the relationship between attitude towards internet and ecommerce among generation $\mathrm{Y}$.

Summary of Findings: In this chapter, the entire hypothesis findings are summarized. In the previous section the hypothesis was tested using multiple regression analysis. The benchmark to test the hypothesis is significance level, which is 0.05 . The following table shows the entire hypothesis tested.

Table 12: Summary of Findings

\begin{tabular}{lll}
\hline \multicolumn{2}{c}{ Descriptive } & $\begin{array}{l}\text { Accepted/Rejected } \\
\text { Hypotheses }\end{array}$ \\
\hline H1 & $\begin{array}{l}\text { Generation Y will have affirmative attitude toward } \\
\text { internet on their e-commerce. }\end{array}$ & Accepted \\
H2 & $\begin{array}{l}\text { There will be significant relationship between gender and } \\
\text { attitude towards internet among generation Y } \\
\text { Gender moderate the relationship between attitude } \\
\text { toward internet and e-commerce among generation Y }\end{array}$ & Accepted \\
Accepted \\
\hline
\end{tabular}

Discussion: This section, discusses each objective that are reviewed and explained with reasonable explanation according to the findings of this study. The results from the findings in this study are important for next Malaysian generation in relation to their computer literacy, attitude towards internet and their e-commerce activities. Since the generation Y is dominating Malaysian population pyramid and in addition this generation is someway existing and entering workforce and starting to earn money. Furthermore the result may helps to gain deeper understanding of generation Y characteristic in relation with computer literacy, attitude towards internet and lastly e-commerce. This study may contribute to the body of knowledge at academicals level and provide some useful information for e-commerce companies to formulate the strategy in order to boost their sales and focusing on generation $\mathrm{Y}$ consumer.

Generation Y will have affirmative attitude toward internet on their e-commerce: The first objective in this study is to analyze generation $\mathrm{Y}$ attitude towards internet. According to the first hypothesis (H1) test indicates that there is a significant relationship between attitude towards internet and their ecommerce. This study found that Hypothesis (H1) R squared value scores 0.687, it means that 68.7 percent of e-commerce are predicted by attitude towards internet and the rest 31.3 percent are predicted by other factors. The attitude towards internet itself is related to user's positive or negative perspectives closely knit with their internet activities or experiences. Further the purchasing decision is highly influenced by perception (Kottler, 2004). If the consumers are having positive view about internet technology then there is high possibility to utilize internet for e-commerce activities. Several researches have been done in order to relate the relationship between attitude towards internet and e-commerce. Chiu (2005) has tried to assess the model of online purchase intention and he found that online application such as e-commerce is highly influenced by the site perceive of ease use, or simply the user perception is critical. In line with Chiu (2005), Crisp, Jarvenpaa \& Todd (1997) also found the same findings, they pointed out that positive experience, and positive perspective with similar consumer behavior and web technology is a good predictor of behavioral intention to purchase products or services through electronic environment. Latest research conducted by Jusoh and Ling (2012) reveled attitude towards internet has significant effect to their e-commerce activities. In conclusion the user or customer perspectives about internet, its usage as well as e-commerce bring significant impact to their e-commerce activities.

There will be significant relationship between gender and attitude towards internet among generation Y: The second objective in this study is to ascertain the relationship between gender and attitude towards internet among generation $Y$, in this study the result shows that there is positive relationship between gender and attitude towards internet. The $\mathrm{R}$ square value scores 0.333 , it means gender contribute approximately 33 percent of attitude towards internet. Further the result shows that there is significant relationship between gender and attitude towards internet. In the technological era, like nowadays people have high dependency on internet. Surprisingly in this study it was found that the 
digital divide still exist surround us. There are many factors contributing to the disparity such as income, educational level, class, race, gender, geographical location and cultural differences (Papastergiou \& Solomonidou, 2005). The gender gap in the adoption of internet may exist because male and female are different in the socio economic status on average, thus it will influences their computer and internet access (Bimber, 2000; Ono, 2003). In general male tend to have more hours spending time in the internet compared to female (The Broadband Comission Working Group on Broadband \& Gender, 2013). In addition Ford and Miller (1996) reported that women experienced greater disorientation level and disenchantment in relation to the internet usage compareed to men. Women went online less intense, spent less time to surf digitally and utilized internet for narrower purpose compared to men (Tsai \& Lin, 2007). The result turns substantiali the hypothesis formulated in this study.

Gender moderate the relationship between attitude toward internet and e-commerce among generation Y: The third objective in this study was to analyze the moderating effect of gender and relationship with attitude towards internet and e-commerce. Based on the hypothesis testing, it was predicted a considerable proportion of respondents' attitude towards e-commerce can be predicted by their attitude towards internet with gender as a moderator. Further the result indicated that there is a significant relationship between gender and further it moderate attitude towards internet and ecommerce.As the result from previous hypothesis indicated that gender gap does exist and affecting their attitude towards internet, therefore gender moderate attitude towards internet and e-commerce. This finding is supported by previous research. Many scholars alleged that male and female differ in their processing information. Mainly men and women accept stimuli in consumption such as graphic or text. In addition women accept more response on imagery stimuli while men more intend to text based. This fact may lead to the moderating roles for attitude towards internet and e-commerce (Holbrook, 1986). The influence of gender upon decision making on the e-commerce has been analyzed with regard the process of acceptance of new information technologies. The information technology characteristic and use are evaluated differently, depends on the gender of individual (Venkatesh \& Davis, 2000). The greater attitude towards internet, the greater the number of exchanges and the more positive the attitude towards online shopping (Hernandez, Jimenez, \& Martı́n, 2009).In conclusion it was reported that gender moderating user attitude towards internet and their attitude towards e-commerce.

Implications: There are some implications for policy level, managerial level, as well as for the body of knowledge in the future research; in order to boost e-commerce especially focuses on the next generation.

Policy Level: This study provides a better understanding on generation Y attitude towards usage of internet for e-commerce. In this study reveals that attitude towards internet contribute a large portion to e-commerce. The more positive attitude towards internet, more intense the e-commerce activities. The policy makers, in this case, Ministry of Trading, Ministry of Education and Malaysia Communication and Multimedia Commission (MCMC) should facilitate people of Malaysia to have better training and development initiatives that provide more understanding about internet itself, and with its usage more online consumer purchasing behaviour. The customers can act as better online shoppers and government initiatives can control customer congestions in the retail and shopping malls. Government can act as better facilitator to gain technology skills to their present and upcoming generations and further influence their e-commerce activities. Moreover the government should provide stimulus to small medium enterprise (SME) to transform and innovate their business through provide e-commerce.

Managerial level: This study provides wonderful information about generation $\mathrm{Y}$ attitude towards usage internet for e-commerce. This generation is spending pattern is incredibly high, and they are techno savvy people. In addition generation Y currently entering the workforce and started their earning life. The consumption most probably will be at higher as well. For companies which involve in electronic commerce, this study will provide wonderful information about generation Y. Therefore the companies may plan good strategies in order to get more customers, especially customers from generation Y. For those companies, which have established brick, and mortar, in the future they may provide online services, transforming into brick and click, that further to enhance their business, ultimately getting more customer from generation $Y$.

Theoretical: In the theoretical field, this study adds up a small portion of information to the literature about generation Y, attitude towards internet and electronic commerce. Currently there is a limited resource focus on e-commerce and generation $\mathrm{Y}$ in Malaysian scenario. This study may provide an insight 
to the future research, adding up existing literature with recent findings that support academicians and research scholars to conduct deeper research on e-commerce and generation Y.

\section{Conclusion}

This study is aimed to examine attitude towards usage of internet for e-commerce among generation Y. In the recent years, the trend of internet usage has been increased tremendously. This phenomenon has contributed a great impact to business sector and individuals. The great number of internet users have attracted business to transform their business into digital. The millennial or generation Y, commonly referred as digital native, since their characteristic, which is familiar to technology. Technology is the second environment to this generation. Furthermore generation $\mathrm{Y}$ are dominating the pyramid of population almost all over the world inclusively Malaysia, currently the generation $\mathrm{Y}$ is entering workforce and start earning money. In addition this spending pattern of this generation is quite surprisingly, nearly 1.8 billions ringgit annually in e-commerce only. This generation are looking for more convenient way to shop instead doing conventional way. A huge number of Malaysian generation $\mathrm{Y}$ and their familiarity will open a huge opportunity to utilize technology as the media of business in this digital era that captured the trend.In order to support this study, both primary and secondary data were used. The primary data are gathered through surveys, a set of questionnaire has been distributed to gain deeper understanding regarding their attitude towards internet and e-commerce. Secondly, secondary data such as journal, statistical bulletin also gathered to strengthen and support primary data. The major objective of this study is to analyze the generation $\mathrm{Y}$ attitude towards internet. The results indicated that attitude towards internet contributed considerable proportion and turned to be the predicted factor to their e-commerce activities. It is clearly observed that there is significant relationship between attitude towards internet and e-commerce activities. In addition, there are some other factors influencing attitude towards internet such as gender and computer literacy. Factor such as gender and computer literacy in this study play a major role as moderator toward internet. Further the relationship between gender and computer literacy as a moderator highly is significant. The study provides better insight into the consumer behaviour of Y generation online consumers.

\section{References}

American Express. (2012). American Express Business Insight. New York: American Express. Atlas, C. (2000). Increase seen in internet shopping. Cyber Atlas.

Bartlett, J. E., Kotrlik, J. W. \& Higgins, C. C. (2001). Organizational Research: Determining Appropriate sample Size in Survey Research. Information Technology, Learning, and Performance Journal, 19(1), 43-50.

Bimber, B. (2000). Measuring the Gender Gap on the Internet. Social Science Quarterly, 81(3), 868.

Blakewell, C. \& Mitchell, V. (2003). Gen Y female consumer decision-making styles. International Journal of Retail and Distribution Management, 31(2), 95-106.

Brafton Editorial. (2012). Gen Y spending more than others in ecommerce. Retrieved March 18, 2014, from Brafton: http://www.brafton.com/news/gen-y-spending-more-than-others-in-ecommerce

Castells, M. (2000). The rise of network society. Oxford: Wiley Blackwell.

Chiu, Y. B. (2005). Gender differs: assessing a model of online purchase intentions in e-tail service. International Journal of Service Industry Management, 16(5), 416-435.

Crisp, B., Jarvenpaa, S. \& Todd, P. (1997). Individual differences and Internet shopping attitudes and intentions. Working paper, University of Texas at Austin. Retrieved October 17, 2011, from http://informationr.net/ir/12-2/Crisp.html

Djamasbi, S., Siegel, M. \& Tullis, T. (2010). Gen Y, web design and eye tracking. International Journal of Human-Computer Studies. International Journal of Human-Computer Studies, 68(5), 307-323.

Ford, N. \& Miller, D. (1996). Gender differences in Internet perceptions and use. ASLIB Proceeding. London.

Hair, J., Money, A., Samouel, P. \& Page, M. (2007). Research Method for Business. John Willey \& Sons, Ltd.

Hawkins, J. (1985). Computers and girls: Rethinking the issues. Journal of sex roles, 13(3-4), 165-180.

Hernandez, B., Jimenez, J. \& Martı'n, J. (2009). Age, gender and income: do they really moderate online shopping behavior. Online Information Review, 35(1), 113-133.

Holbrook, M. B. (1986). Aims, concepts andmethods for the representation of individual differences. Journal of Consumer Research, 13(3), 337-347.

Joines, J. L., Scherer, C. W. \& Scheufele, D. A. (2003). Exploring motivations for consumer Web use and their implications for e-commerce. Journal Consumer Marketing, 20(2), 90-108. 
Jusoh, Z. M. \& Ling, G. H. (2012). Factor Influencing Consumers' Attitude Towards E-commerce. International Journal of Humanities and Social, 2(4), 223-230.

Keating, L. (2000). The in crowd: retail rushes to keep pace with generation y. Shopping Center World

Korgaonkar, P. K. \& Wolin, L. D. (1999). A multivariate analysis of Web usage. Journal of Advertising Research, 39(2), 53-68.

Kottler, A. \&. (2004). Principles of Marketing. New Jersey: Prentice Hall.

Li, N. \& Kirkup, G. (2007). Gender and cultural differences in Internet use: A study of China and the UK. Computers and Education, 48(2), 301-307.

Lockeheed, M. (1985). Women, Girls and Computers: A First Look at the Evidence. Sex Roles, 13(3/4).

Lockheed, M. E. (1985). Women, Girls, and Computers: A First Look at the Evidence'. Sex Roles: A Journal of Research, 13, 115-122

Lohse, G., Bellman, S. \& Johnson, E. (2000). Consumer Buying Behavior on the Internet. Journal of Interactive Marketing, 14(1), 15-29.

Luan, W. S., Fung, N. S. \& Atan, H. (2008). Gender Differences in the Usage and Attitudes toward the Internet among Student. American Journal of Applied Sciences, 10(2).

Madell, D. \& Muncer, S.(2004). Back from the beach but hanging on the telephone? Englsih adolescents' attitudes and experience of mobile phones and the internet. CyberPsychology \& Behaviour, 7, 359367.

Malaysian Communication and Media Commission. (2010). Annual Report of MCMC.URL: http://www.skmm.gov.my/skmmgovmy/media/General/pdf/ MCMC_AR_ 2010(English).pdf .Retrieved on $24 / 7 / 2014$

Mick, D. G. \& Fournier, S. (1998). Paradoxes of technology: Consumer Cognizance, Emotions and Coping Strategies. Journal of Consumer Research, 25(2), 123-143

Morahan-Martin, L. \& Janet, L. (1998). The gender gap in Internet use: Why men use the Internet more than women-A literature review. Cyber Psychology \& Behavior, 1(1), 3-10.

Muncer, D. M. (2004). Gender differences in the use of the Internet by English. Social Psychology of Education, 7(2), 229-251.

Nachmias, R., Mioduser, D. \& Shemla, A. (2001). Information and Communication Technologies usage by school students in an Israeli school: Equity, gender, and inside/outside school learning issues. Education and Information Technologies, 6(1). URL: http://muse.tau.ac.il/publications/ICT.pdf

Nahmias, E. (2002). When consciousness matters: A critical review of Daniel Wegner'sThe illusion of conscious will. Philosophical Psychology, 15(4), 527-541.

Ono, H. (2003). Gender and the Internet. Social Science Quarterly, 84(1), 111-121.

Papastergiou, M. (2005). Students' mental models of the internet and their didactical exploitation in informatics education. Education and Information Technologies, 10(4), 341-360.

Papastergiou, M., \& Solomonidou, C. (2005). Gender issues in Internet access and favourite Internet activities among Greek high school pupils inside and outside school. Computers \& Education, 44(4), 377-393.

Paris, P. G. (2004). E-Learning: A study on Secondary Students' Attitudes towards Online Web-Assisted Learning. International Education Journal, 5(1).

Rakow, L. F. (1988). Gendered technology, gendered practice. Critical Studies in Mass Communication, 5(1), 57-70.

Roscoe, J. (1975). Fundamaental Research Statistics for The Behavioral Science. New York: Rinehart and Winston.

Schiffman, L. G., Kanuk, L. L. \& Hansen, H. (2008). Consumer Behavior. Upper Saddle River, N.J.: Prentice Hall.

Sekaran, U. (2003). Research Methods for Business: A Skill Building Approach. John Wiley \& Sons, Incorporated.

Sherman, R. C., End, C., Kraan, E., Cole, A., Campbell, J., Birchmeier Z. \& Klausner. (2000). The Internet gender gap among college students: forgotten but not gone? Cyber Psychology and Behavior, 3(5), 885-894.

Sun, H. \& Zhang, P. (2006). The role of moderating factors in user technology acceptance. International Journal of Human-Computer Studies, 64(2), 53-78.

Suri, G. \& Sharma, S. (2013). The Impact of Gender on Attitude Towards Computer Technology and ELearning. International Journal of Engineering Research, 2(2), 132-136.

Swinyard, W. R., \& Smith, S. M. (2003). Why people (don't) shop online: A lifestyle study of the internet consumer. Psychology \& Marketing, 20(7), 567-597. 
The Broadband Comission Working Group on Broadband \& Gender. (2013). Doubling Digital Opportunities: Enhancing The Inclusion of Women \& Girls In The Information Society. New York: UNDP.

Tsai, C. C. \& Lin, S. (2007). Developing an Internet Attitude Scale for High School Student. Computers Education, 37(1), 41-51.

Venkatesh, V. \& Davis, F. (2000). A theoretical extension of the technology acceptance model: Four longitudinal filed. Management Science, 46(2), 186-204.

Venkatesh, V. \& Morris, M. G. (2000). A Longitudinal Field Investigation of Gender Differences in Individual Technology Adoption Decision-Making Processes. Organizational Behavior \& Human Decision Process, 83(1), 33-60. 